\title{
Study on Prevalence of Tardigrades in Tamil Nadu and Species Identification Using Pan-PCR
}

\author{
Abirami $B^{1}$, Ajith Nayagam $B^{1}$, Karthick $L^{1}$, Sai Ramesh $A^{1}$ and Naveen \\ Kumar $\mathbf{V}^{2 *}$ \\ ${ }^{1}$ Department of Biotechnology, Vel Tech High Tech Dr. Rangarajan Dr. Sakunthala \\ Engineering College, Chennai, Tamil Nadu, India \\ ${ }^{2}$ Immugenix Biosciences, Pvt. Ltd., Chennai, Tamil Nadu, India \\ *Corresponding Author: Naveen Kumar V, Immugenix Biosciences, Pvt. Ltd., \\ Chennai, Tamil Nadu, India.
}

Received: August 20, 2021

Published: October 15, 2021

(C) All rights are reserved by Naveen Kumar V., et al.

\begin{abstract}
Tardigrades (water bears) are organisms, capable of surviving in very extreme conditions. These organisms are known to be ubiquitous and are mostly studied for their extremotolerant properties. Many on-going researches in other countries have shown that some of the extremotolerant properties of Tardigrades can be exploited for medical and experimental applications. But it was also observed that, these properties differed in different species of Tardigrades and also depended on their geographical location. In previous geological studies it was observed that the presence of Tardigrades in tropical region was minimal which contradicted their well-known ubiquitous nature. Therefore, in this paper, we examined the prevalence of Tardigrades in some tropical areas of Tamil Nadu and distribution of different species along with studying their different temperature toleration capacity. Thirteen out of twentytwo moss samples collected from different region of Chennai, Coimbatore and Tirunelveli, were screened positive for the presence of Tardigrades. Based on the morphological identification of claws and buccal pharyngeal apparatus, the isolated Tardigrades were distinguished as three different species. Most of the species was distinguished as Milnesium sp., and others as Murrayon sp. and Macrobiotus $s p$. using light and phase contrast (PC) microscopy. The phenotypically identified species were genotypically characterized as Milnesium tardigradum, Macrobiotus sapiens and Paramacrobiotus richtersi respectively using $18 S$ rRNA sequencing. The isolated species were reared in $2 \%$ agarose plates, in order to explore their reproducing ability in fluctuating room temperature. Their survival ability to different temperatures were tested to observe their toleration limit in terms of their capacity to revive after exposure. From the above experiments, it was observed that Milnesium tardigradum displayed higher tolerance to all the different conditions exposed and was concluded that Milnesium tardigradum was highly tolerant when compared to Macrobiotus sapiens.
\end{abstract}

Keywords: Milnesium tardigradum; Paramacrobiotus richtersi; Macrobiotus sapiens; Extremotolerant; Cryptobiosis; Tun State; 18S rRNA Sequencing

\section{Introduction}

Tardigrades are small eukaryotic multicellular micro-animals [1] with more than 1200 existing species, which are also known as water bears or moss piglets [2,3]. They are microscopic invertebrates, that belong to the superphylum of Ecdysozoa similar to
Caenorhabditis elegans, yet belong to a separate phylum Tardigrada in the Animalia kingdom. They are mostly found in marine, freshwater and terrestrial habitats on substrates such as mosses, liverworts, algae and lichens [4,5]. They are popularly studied for their

Citation: Naveen Kumar V., et al. "Study on Prevalence of Tardigrades in Tamil Nadu and Species Identification Using Pan-PCR". Acta Scientific Medical Sciences 5.11 (2021): 42-52. 
extremotolerant properties that they undergo by a process called cryptobiosis.

Cryptobiosis is a phase, in which an organism alters its metabolic activity in response to stressful surroundings, similar to a bear hibernating to escape cold winters. Through previous studies, it is observed that freshwater and terrestrial Tardigrades in particular exhibit extremotolerant properties to various stresses compared to marine Tardigrades [4-9]. During exposure to extreme conditions such as temperature $\left(-253^{\circ} \mathrm{C}\right.$ to $\left.151^{\circ} \mathrm{C}\right)$, pressure (6 to $\left.7.5 \mathrm{MPa}\right)$, ionizing radiations (X-Rays, UV and Gamma radiations), space vacuum and noxious chemicals, they undergo cryptobiosis by transforming themselves into a reversible tun and halting their metabolic process to enter a slowly emerging dormant-like state [8,10-13].

Tardigrades are omnivorous. They feed on mosses, lichens, algae, bacteria, rotifers and nematodes. Some of the species even exhibit cannibalism $[14,15]$. These micro-animals are observed to be cosmopolitan except for tropical conditions and their survivability factors majorly depends on climatic factors such as humidity, pressure, temperature and also pollution level [5]. They are placed next to lichens for the indication of pollution. The lifespan of Tardigrades is around 2 years in normal surroundings which exceeds up to 30 years during cryptobiosis [12,16-18]. It is also observed that their bodily contractions are preserved up to 120 years which exhibits their unique mechanisms to cope with extremities [19].

Many studies reported several molecular mechanisms involved in the toleration properties of Tardigrades. Some of the studies showed that the production of trehalose like compounds were responsible for survival during desiccation $[19,20]$. It was also observed that many proteins played specific role during cryptobiosis [10] such as Dsup proteins to resolve single and double stranded DNA breaks $[13,21]$, and IDPs which forms a waxy coat under the epicuticle to restore fluids during desiccation. Subsequently, many families of heat shock proteins (Hsp 70 and Hsp 90), LEA (Late Embryogenesis abundant) proteins and antioxidants are produced to tolerate extreme conditions until favorable conditions were restored $[11,20,22,23]$.

Cryptobiotic model systems are extensively studied using certain species of Tardigrades, which are: Milnesium tardigradum, Macrobiotus richtersi, Hypsibius dujardini and Paramacrobiotus sp. [6]. Milnesium tardigradum is the most predominant and high stress tolerant species till observed, which has been sent to low orbital space for testing its survival rate and tolerance to cosmic radiations $[10,22,23]$. Hypsibius dujardini is the least stress tolerant species with optical clear bodies $[6,10,32]$ whereas Macrobiotus sp. and Paramacrobiotus sp. are mostly known for their encystment to survive in rapidly changing environmental conditions such as $\mathrm{pH}$, temperature and osmotic shocks [24-26]. The various tolerant mechanisms they exhibit to achieve cryptobiosis and their endemism are explored in many countries, but there are very less studies indicating their presence in India. Thus, in the present study, we investigated different samples collected from some tropical region of Tamil Nadu, India, to check its prevalence and distribution along with their temperature tolerant properties.

\section{Methods}

\section{Sample collection and isolation}

A total of 22 moss and lichen samples from tree barks, rocks and walls were collected from different locations of Chennai, Coimbatore and Tirunelveli as listed in table 1 . The samples were scraped off using knife and scalpel, which were stored in paper bags at room temperature and transported to the laboratory until use. The collected samples were rehydrated using tap water for around 12-16h (overnight incubation if needed) [1,13]. The samples were then screened for Tardigrades after an interval of 2 hours, according to [14] and were isolated using pipettes.

\section{Phenotypic identification of isolated tardigrades}

The isolated Tardigrades were transferred to the glass slide and preliminarily identified based on their morphological structures using Magnus MLX Plus light microscope (Olympus, Japan) [6,27]. The genus of each tardigrade was differentiated based on the structures of buccal-pharyngeal apparatus, claws, armour plates and distance between each pair of legs by comparing previously noted morphologies of each species as per [1,8,33]. Further morphological structures such as length of the body, muscular tissues, buccal lamellae, buccal papillae, buccal-pharyngeal apparatus, legs and each claw were visualized using EVOS FLC Phase Contrast (PC) microscope (Invitrogen, UK) [27].

Genotypic identification: Primer designing and gene amplification

Twenty-two $18 S$ rRNA tardigrade gene sequences were retrieved from GenBank, NCBI listed in table 2. The following, 


\begin{tabular}{|c|c|c|}
\hline Sample no. & Coordinates & Place \\
\hline TM01 & $8^{\circ} 56^{\prime} 45.9^{\prime \prime} \mathrm{N} 77^{\circ} 12^{\prime} 54.3^{\prime \prime} \mathrm{E}$ & \multirow{8}{*}{ Tirunelveli } \\
\hline TM02 & $8^{\circ} 58^{\prime} 56.8^{\prime \prime} \mathrm{N} 77^{\circ} 13^{\prime} 16.9^{\prime \prime} \mathrm{E}$ & \\
\hline TM03 & $8^{\circ} 59^{\prime} 08.9^{\prime \prime} \mathrm{N} 77^{\circ} 13^{\prime} 11.3^{\prime \prime} \mathrm{E}$ & \\
\hline TM04 & 859'10.8” N 77²13'12.1"E & \\
\hline TM05 & 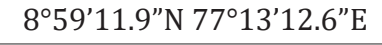 & \\
\hline TM06 & 859'13.2”N 77¹3'13.4"E & \\
\hline TM07 & $8^{\circ} 59^{\prime} 14.9^{\prime \prime} \mathrm{N} 77^{\circ} 13^{\prime} 14.6^{\prime \prime} \mathrm{E}$ & \\
\hline TM08 & 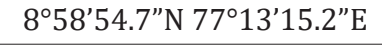 & \\
\hline TM09 & $10^{\circ} 57^{\prime} 58.5^{\prime \prime} \mathrm{N} 77^{\circ} 02^{\prime} 01.2^{\prime \prime} \mathrm{E}$ & \multirow{12}{*}{ Coimbatore } \\
\hline TM10 & $10^{\circ} 57^{\prime} 58.2^{\prime \prime} \mathrm{N} 77^{\circ} 02^{\prime} 01.2^{\prime \prime} \mathrm{E}$ & \\
\hline TM11 & $10^{\circ} 57^{\prime} 57.7^{\prime \prime} \mathrm{N} 77^{\circ} 02^{\prime} 01.4^{\prime \prime} \mathrm{E}$ & \\
\hline TM12 & $10^{\circ} 53^{\prime} 51.1^{\prime \prime} \mathrm{N} 77^{\circ} 00^{\prime} 34.2^{\prime \prime} \mathrm{E}$ & \\
\hline TM13 & $10^{\circ} 54^{\prime} 10.9^{\prime \prime} \mathrm{N} 77^{\circ} 10^{\prime} 36.6^{\prime \prime} \mathrm{E}$ & \\
\hline TM14 & $10^{\circ} 52^{\prime} 46.7^{\prime \prime} \mathrm{N} 77^{\circ} 11^{\prime} 29.5^{\prime \prime} \mathrm{E}$ & \\
\hline TM15 & $10^{\circ} 52^{\prime} 34.7^{\prime \prime} \mathrm{N} 77^{\circ} 11^{\prime} 30.2^{\prime \prime} \mathrm{E}$ & \\
\hline TM16 & 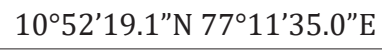 & \\
\hline TM17 & $10^{\circ} 49^{\prime} 44.9^{\prime \prime} \mathrm{N} 77^{\circ} 11^{\prime} 36.2^{\prime \prime} \mathrm{E}$ & \\
\hline TM18 & $10^{\circ} 44^{\prime} 48.3^{\prime \prime} \mathrm{N} 77^{\circ} 04^{\prime} 17.4^{\prime \prime} \mathrm{E}$ & \\
\hline TM19 & 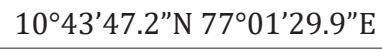 & \\
\hline TM20 & $10^{\circ} 49^{\prime} 44.8^{\prime \prime} \mathrm{N} 77^{\circ} 11^{\prime} 36.1^{\prime \prime} \mathrm{E}$ & \\
\hline TM21 & $13^{\circ} 06^{\prime} 05.5^{\prime \prime} \mathrm{N} 80^{\circ} 14^{\prime} 13.9^{\prime \prime} \mathrm{E}$ & \multirow[t]{2}{*}{ Chennai } \\
\hline TM22 & $13^{\circ} 06^{\prime} 05.1^{\prime \prime} \mathrm{N} 80^{\circ} 14^{\prime} 15.7^{\prime \prime} \mathrm{E}$ & \\
\hline
\end{tabular}

Table 1: Geographical data of samples.

EuT18S-F - forward (5'-AATGRGTACACTTTAAATCC-3') and Eu18S$\mathrm{R}$ - reverse (5'-CTGTTATTGCTCAATCTCGTG-3') pan-primers were designed based on conserved and homologous region of the gene sequences using sequence alignment editor tool, BioEdit version 7.0.9 (Isis Pharmaceuticals), and their specificity was checked using Primer Blast, NCBI. The primers were synthesized at Indigenous DNA (India). In the sequence design, R represent the degeneracy of the bases A and $\mathrm{G}$ in the particular position.

Genomic DNA was extracted from cultivated eleven similar triple washed adult Tardigrades using QIAGEN DNeasy Blood and Tissue kit (Qiagen, Germany) according to the manufacturer's protocol with prolonged heating time $(\sim 45 \mathrm{~min})$ for lysis. A pan-PCR targeting $18 S$ rRNA gene was performed for the isolated Tardigrades with $25 \mu \mathrm{L}$ reaction volume consisting of $1 \mu \mathrm{L}$ of forward and

\begin{tabular}{|l|c|}
\hline Taxa & Genbank accession no. \\
\hline Echiniscus granulates & DQ839606.1 \\
\hline Echiniscoides sigismundi & EU266960.1 \\
\hline Echiniscus testudo & DQ839607.1 \\
\hline Echiniscus viridissimus & AF056024.1 \\
\hline Halobiotus stenostomus & AY582121.1 \\
\hline Hebesuncus conjugens & AM500646.1 \\
\hline Hypsibius cf. convergens & AM500650.1 \\
\hline Hypsibius cf. convergens 1 & AM500647.1 \\
\hline Hypsibius klebelsbergi & AM500648.1 \\
\hline Hypsibius scabropygus & AM500649.1 \\
\hline Isohypsibius cambrensis & AM500652.1 \\
\hline Isohypsibius granulifer & AM500651.1 \\
\hline Macrobiotus sp. & U32393.1 \\
\hline Macrobiotus hufelandi & X81442.1 \\
\hline Macrobiotus sapiens & DQ839601.1 \\
\hline Milnesium tardigradum & AY582120.1 \\
\hline Paramacrobiotus aerolatus & DQ839602.1 \\
\hline Paramacrobiotus tonollii & DQ839605.1 \\
\hline Paramacrobiotus richtersi & DQ839603.1 \\
\hline Ramazzottius oberhaeuseri & AY582122.1 \\
\hline Richtersius coronifer & \\
\hline
\end{tabular}

Table 2: Accession number of the retrieved sequences from NCBI.

reverse broad-range Eutardigrades $18 S$ rRNA primers designed in the present study (10 pM of each primer), $10 \mathrm{mM}$ of dNTP mix (Bio Basic Inc, Canada), $2.5 \mu \mathrm{L}$ of $10 \times$ PCR buffer (15mM $\left.\mathrm{MgCl}_{2}\right), 0.1 \mu \mathrm{L}$ consist of $0.5 \mathrm{U}$ of Taq DNA polymerase (Genet Bio Co, South Korea), $1 \mu \mathrm{L}$ DNA template and $16.8 \mu \mathrm{L}$ PCR grade water.

The pan-PCR amplification was performed in Veriti 96-Well Thermal Cycler (Applied Biosystems, USA) with initial denaturation at $94^{\circ} \mathrm{C}$ for $5 \mathrm{~min}$ followed by 35 cycles of denaturation at $94^{\circ} \mathrm{C}$ for $45 \mathrm{~s}$, annealing at $52^{\circ} \mathrm{C}$ for $30 \mathrm{~s}$ and extension at $72^{\circ} \mathrm{C}$ for $45 \mathrm{~s}$, and with final extension at $72^{\circ} \mathrm{C}$ for $5 \mathrm{~min}$. Known positive and negative controls were also included. To increase the yield of the PCR product a modified nested PCR was carried out using same primers as similar to the protocol of [34]. 
The obtained 18S rRNA pan-PCR amplicons were resolved along with 100 bp DNA markers (Genet Bio Co, South Korea) in 1\% agarose with ethidium bromide $(10 \mathrm{mg} / \mathrm{mL})$ by gel electrophoresis for $\sim 25 \mathrm{~min}$ at $135 \mathrm{~V}$ using Mupid-exU system (Takara, Japan) and gel was analysed by BioGlow UV Transilluminators (Crystal Technology, USA).

\section{$18 S$ rRNA gene sequencing and phylogenetic analysis}

The $18 S$ rRNA pan-PCR amplicons were purified by gel excise method using FavorPrep GEL/PCR Purification kit (Favorgen Biotech Corp, Taiwan). Purified PCR amplicons of the $18 S$ rRNA gene was sequenced in both directions using the specific primers described. Sequencing was carried out at Macrogen Inc. (Seoul, Korea) using ABI PRISM ${ }^{\circledR}$ BigDye $^{\mathrm{TM}}$ Terminator and ABI 3730XL sequencer (Applied Biosystem, USA).

The obtained forward and reverse sequences of $18 S$ rRNA gene pan-PCR product were trimmed, edited and aligned for contig using Bio-Edit software version 7.0.9 (Isis Pharmaceuticals). The $18 \mathrm{~S}$ rRNA gene sequences were compared with known sequences in NCBI Database by using BLAST analysis (http://www.ncbi.nlm.nih. gov/ BLAST/) and the sequences were deposited in the NCBI GenBank database and accession numbers were obtained.

Phylogentic cluster analysis of the present study $18 S$ rRNA gene sequences along with retrived database sequences was conducted with MEGA 7.0 (software) using the neighbourhood joining (NJ) method. Robustness of the nodes was tested by bootstrapping with 500 replicates.

\section{Tardigrade culture}

Isolated Tardigrades from sample were cultured on 2\% agarose gel plates with KCM solution and was maintained at fluctuating temperature of range $20-25^{\circ} \mathrm{C}$. Around $10-15$ individuals of Tardigrades were picked and transferred to the petri plates along with the addition of a mixture of Scenedesmus sp. and Chlorella sp. or cultured nematode isolated from TM08 as feed according to [15,22]. The Tardigrades growth progress was observed each day and recorded. Sub-culturing of Tardigrades was done once in 2 weeks $[6,10,13,14,32]$.

Studies on temperature toleration of different species of Tardigrades

Cultivated species of M.tardigradum and M.sapiens were observed for their toleration capacity when exposed to different temperature by disturbing their ideal temperature $\left(20-21^{\circ} \mathrm{C}\right)$. The different conditions included exposure of Tardigrades to sudden heating, disturbing their thermostat to room temperature and overnight incubation at $4^{\circ} \mathrm{C}[28]$.

During sudden heat application, triple washed cultivated Tardigrades, were placed on microscopic slides and were exposed to fire from beneath the slide for about $\sim 20-35$ sec until the sample droplet dried containing Tardigrades. For disturbing their thermostat to room temperature, 10-15 Tardigrades were reared in fluctuating conditions of temperature, where they were kept in chamber with ideal temperature for first 12 hours and then in room temperature for the next 12 hours. Similarly, to induce cold conditions, around 10-15 Tardigrades were incubated at $4^{\circ} \mathrm{C}$ overnight. After exposure of Tardigrades to all the above conditions, before and after the restoration of normal conditions were observed under Magnus MLX Plus light microscope (Olympus, Japan).

\section{Results}

\section{Screening test results}

Thirteen samples were screened positive with three different groups of species identified as Milnesium sp., Murrayon sp., and Macrobiotus sp. (Table 3) morphologically. Around 84\% of the positive samples showed similar phenotype as of Milnesium sp.

\section{Phenotypic characteristics of isolated Tardigrades}

Milnesium $s p$. was identified by their unique reddish brown pigmented slender bodies with protruding buccal lamellae, buccal papillae and two lateral papillae [4]. Their claw morphology was distinguished with two primary claws and six secondary claws on each leg (Figure 1(a-c)). TM10 sample consisted of both Murrayon sp. and Milnesium sp., where Murrayon sp. was dominant when compared to latter. Murrayon $s p$. was identified by their plump bodies with transparent guts and ' $V$ ' like shaped claws present on legs (Figure 1(d-f)) [29]. TM21and TM22 samples consisted of Macrobiotus sp., which was identified by their plump and large bodies with protruding peribuccal lamellae with a buccal ring as illustrated by [33]. They had L-shaped claws (Figure 1(g-i)) [1]. Both Murrayon sp. and Macrobiotus sp. lacked buccal and lateral papillae.

\section{Genotypic identification of tardigrades}

The $18 S$ rRNA specific pan-PCR products visualized after gel electrophoresis, showed an expected band size of 936bp (Figure 


\begin{tabular}{|c|c|c|c|}
\hline $\begin{array}{l}\text { Sample } \\
\text { no. }\end{array}$ & Type of sample & Screening test & Phenotypic identification \\
\hline TM01 & Liverworts & Negative & - \\
\hline TM02 & Mosses from Ficus religiosa & Positive & Milnesium sp. \\
\hline TM03 & Mosses from Ficus benghalensis & Positive & Milnesium sp. \\
\hline TM04 & Mosses from Ficus benghalensis & Positive & Milnesium sp. \\
\hline TM05 & Mosses from Ficus benghalensis & Positive & Milnesium sp. \\
\hline TM06 & Mosses from Ficus benghalensis & Positive & Milnesium sp. \\
\hline TM07 & Mosses from Azadirachta indica & Negative & - \\
\hline TM08 & Mosses from Ficus religiosa & Positive & Milnesium sp. \\
\hline TM09 & Algae grown on soil & Negative & - \\
\hline TM10 & Mosses from Ficus religiosa & Positive & Murrayon sp. \& Milnesium sp. \\
\hline TM11 & Bryophytes from walls & Negative & - \\
\hline TM12 & Mosses from Azadirachta indica & Positive & Milnesium sp. \\
\hline TM13 & Mosses from stones & Negative & - \\
\hline TM14 & Mosses \& lichens from Cocus nucifera & Positive & Milnesium sp. \\
\hline TM15 & Mosses from Arecaceae & Positive & Milnesium sp. \\
\hline TM16 & Mosses from Albizia lebbeck & Positive & Milnesium sp. \\
\hline TM17 & Mosses from rocks & Negative & - \\
\hline TM18 & Mosses from rocks & Negative & - \\
\hline TM19 & Mosses from Arcea catechu & Negative & - \\
\hline TM20 & Mosses from Tamarindus indica & Negative & - \\
\hline TM21 & Mosses from Azadirachta indica & Positive & Macrobiotus sp. \\
\hline TM22 & Mosses from Azadirachta indica & Positive & Macrobiotus sp. \\
\hline
\end{tabular}

Table 3: Screening test results.
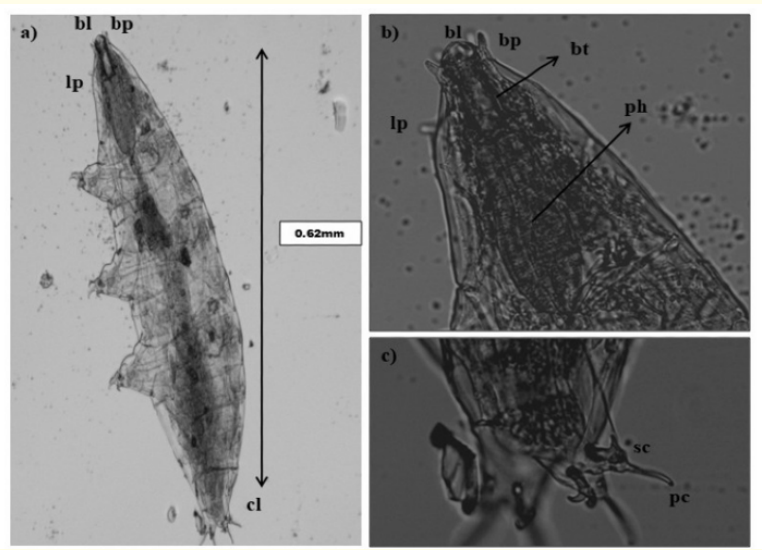

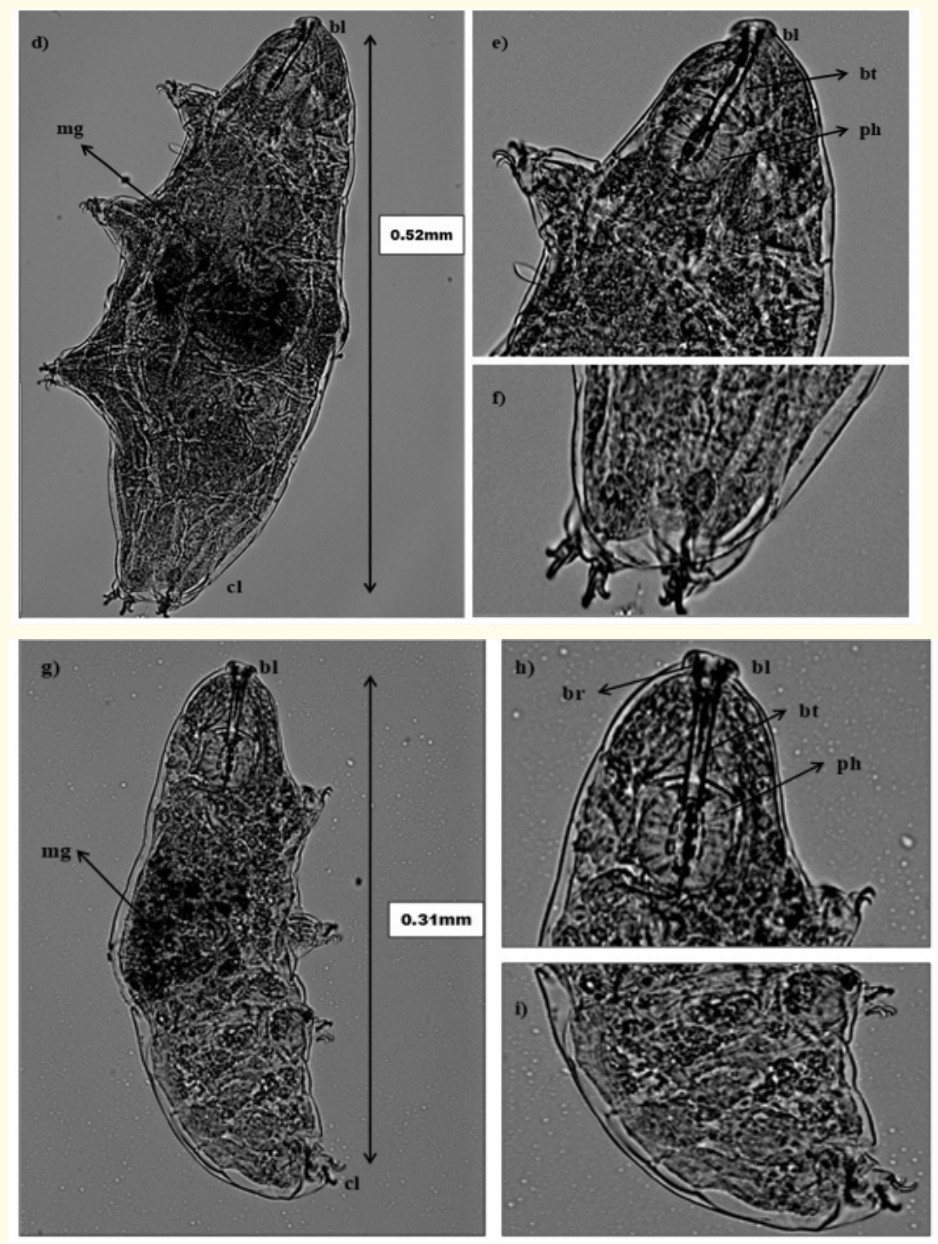

Figure 1: Phase contrast images of isolated Tardigrades (a-c): a) Milnesium tardigradum phenotypically identified as Milnesium sp.; b) buccal-pharyngeal apparatus of the specimen; c) claw morphology with distinct primary and secondary claws. (d-f): d) Macrobiotus sapiens phenotypically identified as Murrayon sp. e) buccal-pharyngeal apparatus f) claw morphology. (g-i): g) Paramacrobiotus richtersi phenotypically identified as Macrobiotus sp. h) buccal-pharyngeal apparatus i) claw morphology. Note: bl=buccal lamellae;

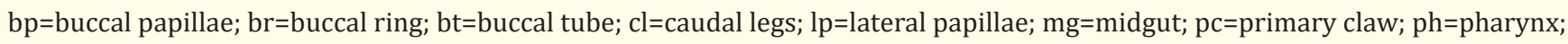
$\mathrm{sc}=$ secondary claw.

2). The phenotypically identified Milnesium sp., Murrayon sp. and Macrobiotus sp. were genotypically (18S rRNA sequence) characterized as Milnesium tardigradum, Macrobiotus sapiens and Paramacrobiotus richtersi respectively using NCBI BLAST tool. The $18 \mathrm{~S}$ rRNA sequences of $M$. tardigradum, $M$. sapiens and $P$. richtersi was deposited in NCBI Genbank database with the accession number MK567640, MK680800 and MK685669 respectively.

The phylogenetic cluster analysis showed that the sequences of both M. tardigradum and M. sapiens were homologous with the database sequence and had trivial genetic variations. Whereas the 


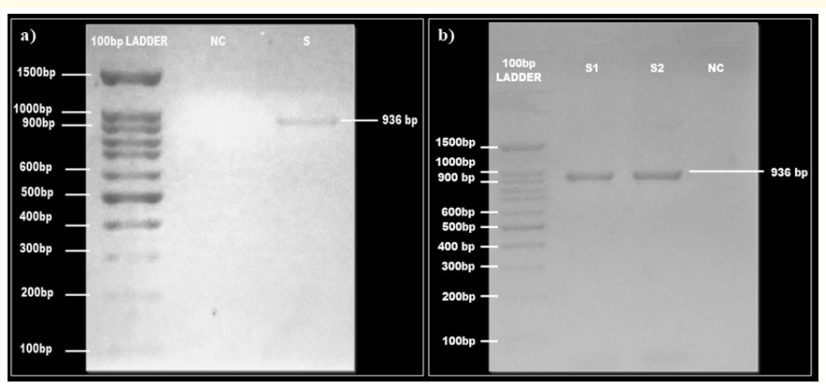

Figure 2: Representative gel for modified nested pan-PCR a) first round pan-PCR product b) second round nested pan-PCR products with different template volume. Note: $\mathrm{S}=$ sample; $\mathrm{S} 1=$ sample 1 with template volume $1 \mu \mathrm{L} ; \mathrm{S} 2=$ sample 2 with template volume $2.5 \mu \mathrm{L} ; \mathrm{NC}=$ negative control.

sequence of $P$. richtersi formed a different lineage, without forming a node with its synonym Macrobiotus richtersi (Figure 3).

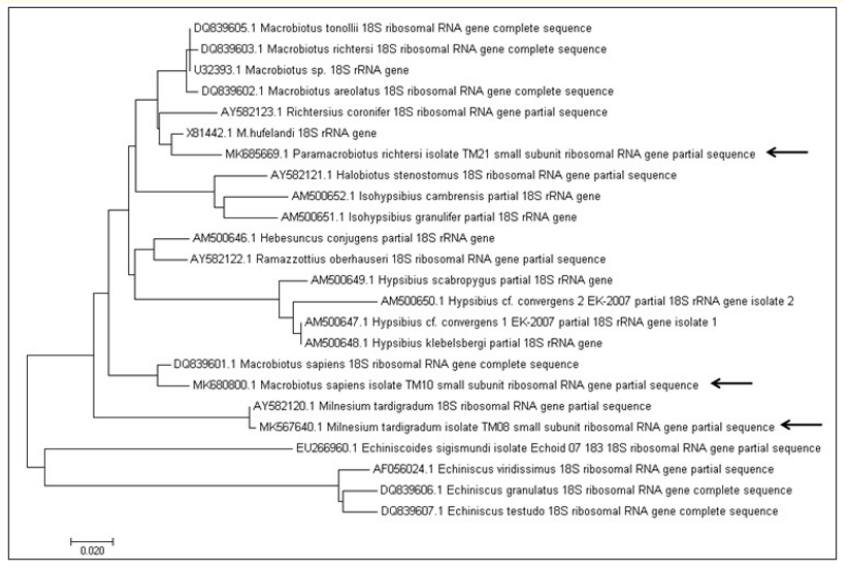

Figure 3: Phylogram obtained from present study $18 S$ rRNA sequenced sequences and sequences retrieved from GenBank, NCBI (Table 2) using Neighbor-joining (NJ) method.

\section{Culturing of tardigrades}

M. tardigradum and M. sapiens were isolated from TM08 and TM10 for understanding the temperature tolerance capacity of a high and less tolerant species respectively. Both the species were reared on 2\% agarose gel plates with a mixture of both Scenedesmus sp. and Chlorella sp. but based on the feeding behavior of $M$. tardigradum, they were also fed with nematodes cultured from respective sample. Their feed intake of algae was very low and a shedded skin was only noted after a week.

In comparison, $M$. sapiens feed intake was appreciably noted with the greenish appearance of the gut and within 3 days of inoculation, the culture plates were recorded with shedded skin. Around 2-4 eggs were observed in the sheds along with eggs dispersed on the gel surface after one week. After 2 weeks, a juvenile tardigrade was observed and the initial count of individuals increased by one. This represented that Macrobiotus sapiens, reproduction capacity was not affected with the fluctuating room temperature but Milnesium tardigradum needed very stringent temperature control and their ability to reproduce was hampered with fluctuating conditions.
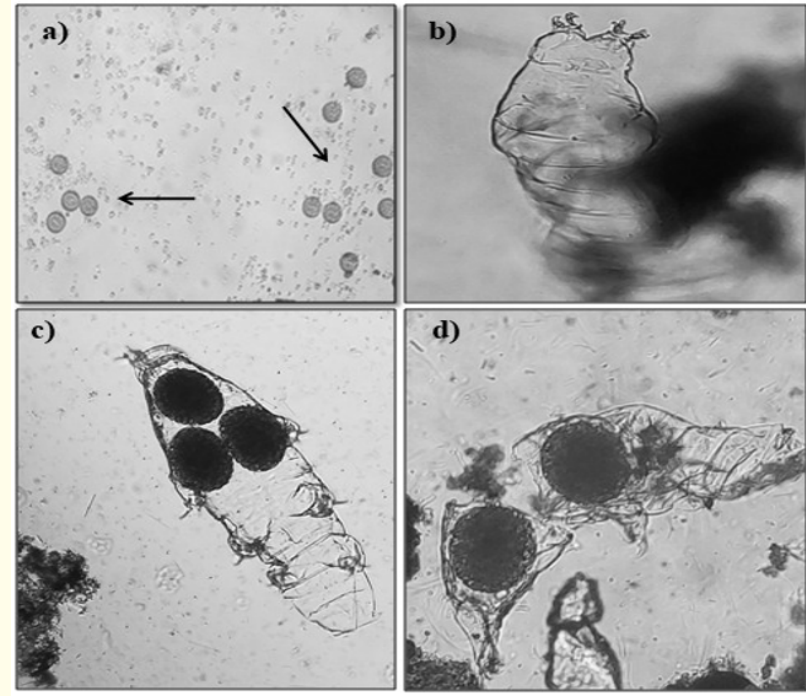

Figure 4: Light microscopic images of a) eggs dispersed over the gel surface; b) shedded skin of M.sapiens; c) shedded skin of $M$. tardigradum bearing three eggs; d) shedded skin of $M$. sapiens along with two eggs.

Temperature tolerant properties of Milnesium sp. and Macrobiotus sp.

Both M. tardigradum and M. sapiens showed varied resistant capacitance to different temperatures. $M$. tardigradum was more 
resistant than $M$. sapiens and was able to regain alive after exposure to stress.

\section{Sudden heating $\left(>150^{\circ} \mathrm{c}\right)$}

M. tardigradum when exposed to sudden heating underwent encystment as similarly illustrated by Guidetti et al. (2011), by shrinking their body inside their outer cuticle (Figure 5 (a)). When rehydrated the body cells regained its original shape and started to bulge out. After resurrection of its original shape, they started to move. Whereas M. sapiens shrinked their body, after exposure without noticeable reduction in their size. After rehydration they were not able to regain their original structure and were dead (Figure $5(b))$.

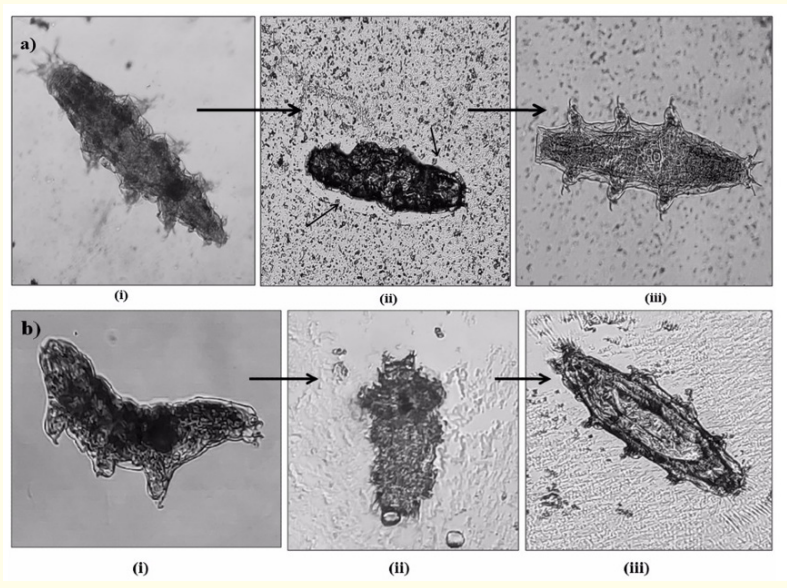

Figure 5: a) (i) M. tardigardum before exposure to heat (ii) Cyst formation by shrinking body inside the outer cuticle indicated with arrow marks (iii) After rehydration; b) (i) M. sapiens before sudden heating (ii) After exposure to heating (iii) Dead individual after rehydration.

\section{Indian room temperature}

M. tardigradum when incubated in Indian room temperature by disturbing their ideal temperature, their activity started to slow down and after 2-3 days their bodies formed a cyst (Figure 6) [11]. After incubation in ideal temperature, their cyst started to grow out to normal body structure. Contradictorily M. sapiens was highly active when incubated in Indian room temperature without any noticeable effect in their activities. They were able to feed, grow and shed skin as normal. Hence, the following observation indicated $M$. sapiens more tolerable to slight variations in the temperature when compared to M. tardigardum.
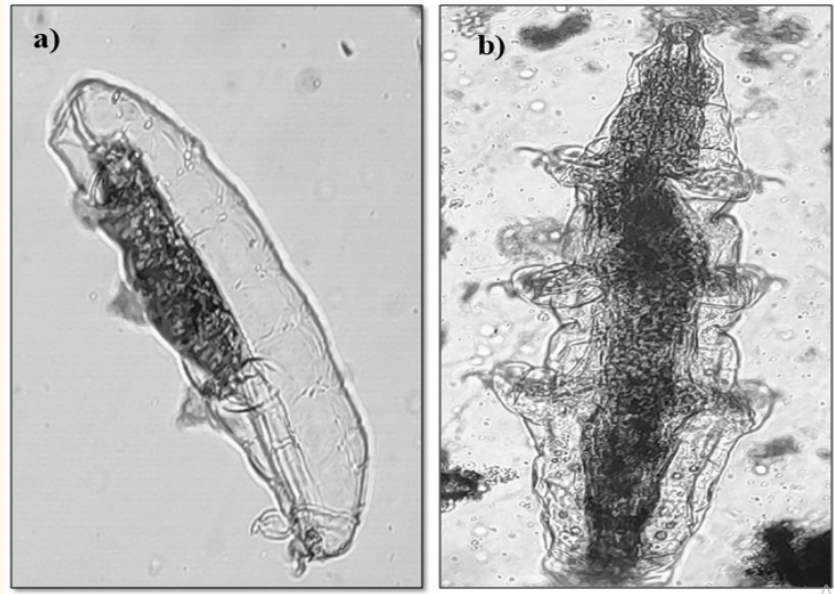

Figure 6: (a) Encyst of $M$. tardigardum after exposure to Indian room temperature; (b) after restoring ideal condition.

\section{Cold temperature}

$M$. tardigradum when incubated at $4^{\circ} \mathrm{C}$ overnight, they transformed into a tun and started to crawl back its original structure by extending their claws and legs out of the tun, after restoration of the normal condition (Figure 7(a)). Whereas, M. sapiens were highly active for the first $8 \mathrm{~h}$ after incubation. After $8 \mathrm{~h}$ they transformed in to a cyst rather a tun. When conditions were restored, they were not able to regain back alive and started to exudate their internal components (Figure 7 (b)).

\section{Discussion}

The current study aimed to check the prevalence and distribution of Tardigrades in Tamil Nadu, along with their temperature tolerant properties. Out of 22 collected samples, only 13 samples showed their presence, which mostly included mosses and lichens from tree barks. One of the possible reasons for their absence could be due to the texture of mosses found in the rocks and walls being thick [1], that made Tardigrades unable to use their stylets to feed. Also, there are higher chances of displacement of Tardigrades from a particular region to another due to rain or some other climatic conditions [3]. When the samples were rehydrated for 2-3 days, 

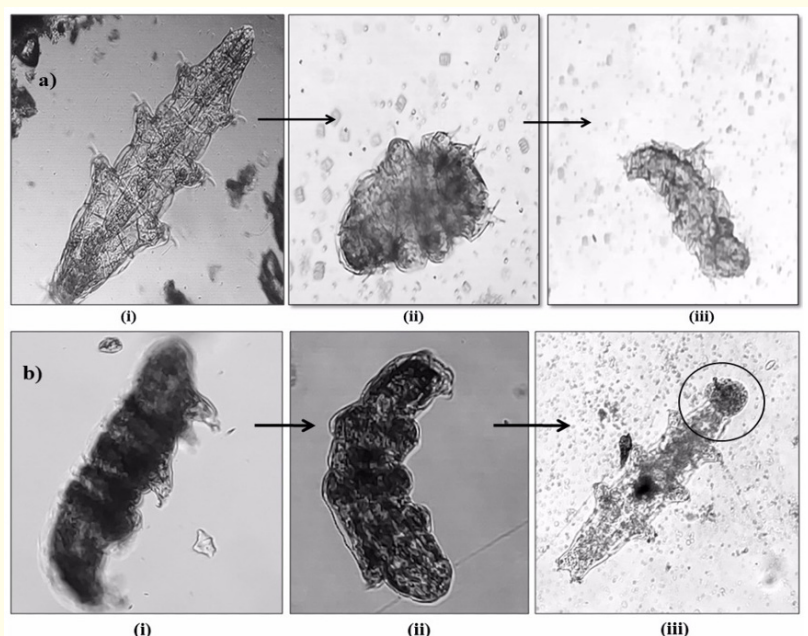

(iii)
Figure 7: (a) (i) M. tardigradum before incubation at $4^{\circ} \mathrm{C}$ (ii) Tun formation after overnight incubation (iii) After restoration of normal condition; (b) (i) M. sapiens before incubation at $4^{\circ} \mathrm{C}$ (ii) After $8 \mathrm{~h}$ of incubation (iii) Exudation of internal compounds after persistent overnight incubation and restoration of normal conditions (Exudation marked by circle).

Tardigrades bulged out and attained their full body length. This condition occurs mainly due to one of the three reasons: (i) oxygen depletion (ii) pseudo-simplex stage I (iii) dead $[1,8,28]$. Another reason could be that the Tardigrades might have died because of starvation; since resurrected after unknown number of days of tun state. Even though, they are known to survive anhydrobiosis, Tardigrades cannot survive after reviving, if their food or storage reserves are depleted to maintain their metabolism over years [16]. Consequently, most of the samples consisted of Milnesum sp., indicates their survival ability and higher toleration capacity to various geographical region and stress.

The positively screened sample TM10, consisted of two species $M$. sapiens and M. tardigradum. But when the population ratio was taken into account, $M$. tardigardum had low count when compared to $M$. sapiens. This observation might represent a dominance of a particular species over an area or refer M. tardigradum in higher tropical level as most of the studies report Milnesium sp. as carnivores as well as a cannibal. Sample TM21 and TM22 were collected from the localities of Chennai, was observed with P. richtersi. The number of individuals found were less and were structurally small when compared to screening of other samples, which may be an indication of pollution level in the particular area [8], as Chennai stands as one of the most polluted cities of India.

The phenotypic identification of Milnesium $s p$. showed a very unique morphology as stated by [1]. Their buccal region contains peribuccal lamellae and lateral papillae, which are not present in other species of Eutardigrades. The phenotypically identified Murrayon $s p$. was genotypically characterized as M. sapiens. This shows a remarkable morphological similarity between the two species which cannot be determined when identified phenotypically [31] as both the species are from the same family Macrobiotidae. The difference in their morphology is stated by the difference in the shape of claws as V-shaped and L-shaped for Murrayon sp. and Macrobiotus sp. respectively [8] which cannot be distinguished easily under the microscope. Thus, the identification of Tardigrades using phenotypic methods is not accurate as many genera exhibit similar morphology and there are chances of misidentification of the genus as done in the present study. Therefore, it is necessary to promote genotypic methods for the correct identification of the species.

The phylogenetic tree construction, showed a different lineage for $P$. richtersi, different from its synonym group $M$. richtersi. This raises a question for the authenticity of the sequence obtained or present in the database. Or which can be explained by variation of some bases in the sequence collected during sequencing.

During exposure to sudden heating, $M$. tardigradum was able to come alive after restoration of normal conditions, but their activity was greatly reduced which is in accordance with the results [20]. Also, [20] reasoned this fact by the incapability of producing heat protectants by Tardigrades in a very short period of time, which is quite lethal. Documenting it again; it goes in accordance with previous literature. Further M. tardigradum tries to adapt to different conditions for survival which, provides a direct evident that it is universally prevalent. Future studies and experiments can be done to understand about their survival mechanism and how their proteins are involved for adaptations.

In an overview, the temperature tolerant studies between $M$. tardigardum and $M$. sapiens showed that M. tardigradum was more 
capable of toleration when exposed to different temperature as similar to [22]. M. tardigradum underwent different types of cryptobiotic states, as per the conditions exposed and was able to regain alive after conditions were restored. Comparatively, M. sapiens were very sensitive to high temperature, but were much tolerant to a particular range of mesophilic conditions, without switching on to cryptobiotic state immediately.

\section{Conclusion}

The present study indicates the prevalence of Tardigrades in TamilNadu, and shows that Milnesium sp. are highly distributed when compared to other species. The comparison between phenotypic and genotypic studies of the isolated Tardigrades reveals that, species under the same family share similar body structures which cannot be identified morphologically and shows the advantage of genotyping method. The studies conducted for the temperature tolerant capacity indicates $M$. tardigradum are highly resistant to any change in temperature and survive alive after restoration of the ideal conditions when compared to M. sapiens.

\section{Bibliography}

1. Mathews GB. "Tardigrada from North America". The Unive] sity of Notre Dame 19.3 (1938): 619-627.

2. Guidetti R and Bertolani R. "Tardigrade taxonomy: an updated check list of the taxa and a list of characters used in their ider tification". Zootaxa 845.1 (2005): 1-46.

3. Degma P., et al. "Actual Checklist of Tardigrada species". (200؟ 2018, 34 ${ }^{\text {th }}$ Edition: 30-06-2018) R (2009-2018).

4. Higgins PR. "Life History of Macrobiotus islandicus Richters withnotes on Other Tardigrades from Colordo". Transactions of the American Microscopical Society 78.2 (1959): 137-154.

5. Nelson DR. "Current status of the Tardigrada: Evolution and Ecology". Integrative and Comparative Biology 42.3 (2002): 652-659.

6. Gabriel NW., et al. "The tardigrade Hypsibius dujardini, a ne' model for studying the evolution of development". Develol mental Biology 312.2 (2007): 545-559.

7. Rebecchi L., et al. "Resistance of the anhydrobiotic eutardigrade Paramacrobiotus richtersi to space flight (LIFE-TARSE mission on FOTON-M3)". Journal of Zoological Systematics and Evolutionary Research 49.s1 (2011): 98-103.

8. Nelson DR., et al. "Chapter 17: Phylum Tardigrada”. In James, H., Thorp, D. and Christopher, Rogers. (Ed.), Thorp and Covich's Freshwater Invertebrates (Fourth Edition). NY: Ecology and General Biology (2015): 347-380.

9. Savic GA., et al. "New multivariate image analysis method for detection of differences in chemical and structural composition of chitin structures in tardigrade feeding apparatuses". Zoomorphology 135.1 (2016): 43-50.

10. Beltran-Pardo AE., et al. "Sequence analysis of the DNA- repair gene rad 51 in the tardifrades Milnesium cf. tardigradum, Hypsibius dujardini and Macrobiotus cf. harmsworthi". Journal of Limnology 72.1s (2013): e10.

11. Horikawa DD., et al. "Analysis of DNA Repair and Protection in the Tardigrade Ramazzottius varieornatus and Hypsibius dujardini after Exposure to UVC Radiation”. PLOS ONE 8.6 (2013): e64793.

12. Jonsson I., et al. "Tolerance to Gamma-Irradiation in eggs of the Tardigrade Richtersius coronifer depends on stage of development". Journal of Limnology $72 . s 1$ (2013): 73-79.

13. Hashimoto $\mathrm{T}$., et al. "Extremotolerant tardigrade genome and improved radiotolerance of human cultured cells by tardigrade-unique protein". Nature Communications 7 (2016): 12808.

14. Alterio T and Rebecchi L. "Rearing Tardigrades: Results and Problems". Zoologischer Anzeiger - A Journal of Comparative Zoology 240.3-4 (2001): 217-221.

15. Schill OR., et al. "Food of tardigrades: a case study to understand food choice, intake and digestion". Journal of Zoological Systematics and Evolutionary Research 49.s1 (2011): 66-70.

16. Rebecchi L., et al. "Dynamics of long-term anhydrobiotic survival of lichen-dwelling tardigrades". Hydrobiologia 558.1 (2006): 23-30.

17. Jorgensen A., et al. "A molecular study of the tardigrade Echiniscus testudo (Echiniscidae) reveals low DNA sequence diversity over a large geographical area". Journal of Limnology 66.1 (2007): 77-83. 
18. Guidetti R., et al. "On dormancy strategies in tardigrades". Journal of Insect Physiology 57.5 (2011): 567-576.

19. Lundström J and Svensson L. "The effect of dehydration rates on anhydrobiotic survival and trehalose levels in tardigrades (Dissertation)". Tsunami 3 (2006).

20. Boothby CT., et al. "Tardigrades use instrinsically disordered proteins to survive desiccation". Molecular Cell 65.6 (2017): 975-984.

21. Jonsson KI. "Causes and consequences of excess resistance $\mathrm{i}$ cryptobiotic Metazoans". Physiological and Biochemical Zoology 76.4 (2003): 429-435.

22. Förster F., et al. "Tardigrade workbench: comparing stress-rı lated proteins, sequence-similar and functional protein clu: ters as well as RNA elements in tardigrades". BMC Genomics 10 (2009): e469.

23. Schokraie E., et al. "Investigating heat shock proteins of tardigrades in active versus anhydrobiotic state using shotgun proteomics". Journal of Zoological Systematics and Evolutionary Research 49.s1 (2011): 111-119.

24. Jonsson KI., et al. "Tardigrades survive exposure to space in low Earth orbit". Current Biology 18.17 (2008): R729-R731.

25. Higgins PR and Crowe HJ. "The Revival of Macrobiotus areolatus Murray (Tardigrada) from the Cryptobiotic State". Transactions of the American Microscopical Society 86.3 (1967): 286294.

26. Koutsovoulos G., et al. "No evidence for the extensive horizontal gene transfer in the genome of the tardigrade Hypsibius dujardini". PNAS 113.18 (2016): 5053-5058.

27. Guidetti R and Møbjerg N. "Environmental Adaptations: Encystment and Cyclomorphosis". In: Schill R. (eds) Water Bears: The Biology of Tardigrades". Zoological Monographs 2, Springer, Cham (2018): 249-271.

28. Guidetti R., et al. "Distribution of calicium and chitin in the tardigrade feeding apparatus in relation to its function and morphology". Integrative and Comparative Biology 55.2 (2015): 241-252.
29. Halberg KA., et al. "Cyclomorphosis in Tardigrada: adaptation to environmental constraints". The Journal of Experimental Biology 212 (2009): 2803- 2811.

30. Guidetti R. "Two new species of Macrobiotidae (Tardigrada: Eutardigrada) from the United States of America, and some taxonomic consideration of the genus Murrayon". Proceeding of the Biological Society of Washington 111.3 (1998): 663-673.

31. Kaczmarek L., et al. "Ecological factors determining Tardigrada distribution in Costa Rica”. Journal of Zoological Systematics and Evolutionary Research 49.1 (2010): 78-83.

32. Cesari M., et al. "DNA Barcoding in Tardigrada: the first case study on Macrobiotus macrocalix Bertolani and Rebecchi 1993 (Eutardigrada, Macrobiotidae)". Molecular Ecology Resources 9.3 (2009): 699-706.

33. Beltran-Pardo AE., et al. "Tolerance to Gamma radiation in the tardigrade Hypsibius dujardini from embryo to adult correlate inversely with cellular proliferation". PLOS ONE 10.7 (2015): e0133658.

34. Pilato G. "Structure, itraspecific variability and systematic value of the buccal armature of Eutardigrades". Journal of Zoological Systematics and Evolutionary Research 10.1 (1972): 65-78.

35. Welnicz W., et al. "ITS-2 and 18S rRNA data from Macrobiotus polonicus and Milnesium tardigradum (Eutardigrada, Tardigrada)". Journal of Zoological Systematics and Evolutionary Research 49.s1 (2011): 34-39.

\section{Volume 5 Issue 11 November 2021 \\ (C) All rights are reserved by Naveen Kumar V., et al.}

